Portland State University

PDXScholar

7-29-1975

\title{
Martin Luther's concept of the church : its implications for the layman
}

William W. Dean

Portland State University

Follow this and additional works at: https://pdxscholar.library.pdx.edu/open_access_etds

Part of the Christianity Commons, History of Christianity Commons, Intellectual History Commons, and the Religious Thought, Theology and Philosophy of Religion Commons Let us know how access to this document benefits you.

\section{Recommended Citation}

Dean, William W., "Martin Luther's concept of the church : its implications for the layman" (1975). Dissertations and Theses. Paper 2254.

https://doi.org/10.15760/etd.2251

This Thesis is brought to you for free and open access. It has been accepted for inclusion in Dissertations and Theses by an authorized administrator of PDXScholar. Please contact us if we can make this document more accessible: pdxscholar@pdx.edu. 
AN ABSTRACT OF THE THESIS OF William $W$. Dean for the Master of Arts in History presented July 29, 1975.

Title: Martin Luther's Concept of the Church: Its Implications for the Layman.

APPROVED BY MEMBERS OF THE THESIS COMMITTEE:

Susan Karant-Kunn, Chairman

Jon Maxdaville

This paper is a study of the relationship between Martin Luther's theology of the church and the practical development of the religious life of the church under his leadership, as this relationship relates to the active and passive roles of the layman in the church. The thesis question is: Did Luther hold a social prejudice against the lower classes and in favor of the upper class that caused him to modify or reinterpret his concept of the church in the course of his career?

The research data were drawn from two resource areas. 
Primarily the data come from a review of Luther's writings. Additional information and interpretation comes from outstanding secondary works on this area of Luther's thought.

The data revealed a dualism in Luther's thinking on the nature of the church that reflected $h$ is doctrine of the two kingdoms. This dualism took two forms: between the Christian man in the church and in the world, and between the spiritual, invisible church and the visible, external church. Luther sought to justify the union of the possibly conflicting roles of man as a holy, believing saint and a sinful, fully participating member of earthly society; and the possibly conflicting views of the church as the holy communio sanctorum under the rule of Christ, and as an institutional body constituted under earthly authority. The data presented here have been organized under three general divisions: The Christian in the Church, the Christian in the World, and the Church in the World.

The conclusions of the study are twofold. First, Luther's attitude toward the people was not prejudice as such, but pessimism: he disliked thein ignorance and crudeness, doubted their ability or willingness to live as he felt Christians should, but was nevertheless deeply interested in their spiritual welfare. Secondly, certain of Luther's own unconscious presuppositions involving political and social conservatism and reactions to radical reformers and sects undercut his theological idealism as revealed in 
the doctrine of priesthood of the believer. This resulted in the de-emphasis of the spiritual quality of life in the church as the community of believers, and a concurrent emphasis on authority, obedience, and only passive participation by the people in the church as a social and quasipolitical institution. 
MARTIN LUTHER'S CONCEPT OF THE CHURCH:

ITS IMPLICATIONS FOR THE LAYMAN

by

WILLIAM W. DEAN

A thesis submitted in partial fulfillment of the requirements for the degree of

\author{
MASTER OF ARTS \\ in \\ HISTORY
}

Portland State University

1975 
TO THE OFFICE OF GRADUATE STUDIES AND RESEARCH:

The members of the Committee approve the thesis of William W. Dean presented July 29, 1975.

Susan Karant-Nunn, Chairman

Jon/Mandaville

APPROVED:

Jesse L. Gilmore, Head, Department of History

Dăvid T. Clark, Dean of Graduate Studies and Research

July 29,1975 
TABLE OF CONTENTS

CHAPTER

PAGE

I INTRODUCTION . . . . . . . . . . . 1

The Thesis Question. . . . . . . 2

The Theoretical Framework. . . . . . 3

Limitations and Boundaries . . . . . 5

Method of Procedure. . . . . . . . 6

II THE CHRISTIAN IN THE CHURCH. . . . . . . 8

Luther's Definition of the Church. . . 10

The Invisible Church

The Visible Church

The Believer-Priest. . . . . . . 13

The Ministry of the Word

The Ministry of Absolution

The Ministry of Judging Doctrine

The Freedom of the Christian . . . . 19

Authority in the Church. . . . . . 21

The Bishop or Superintendent

The Pastor

III THE CHRISTIAN IN THE WORLD . . . . . . 26

Luther's Two Kingdoms. . . . . . . 28

God's "Invisible Kingdom"

The Two Kingdoms

Obedience and Order. . . . . . . 33

Obedience and Suffering. . . . . . 36

The Unjust Ruler. . . . . . . . 38

The Christian's Role in Government . . 41 
IV THE CHURCH IN THE WORLD. . . . . . . . . . 44

The Signs of the Church. . . . . . . 47

The Parish Church

The Sanctified Church

The Disciplined Church

Luther's View of Peasants and Princes. . 56

The Common People

The Nobility

$\mathrm{V}$ CONCLUSTON • . . . . . . . . . . . . 66

Luther and the Church. . . . . . . 66

Countercurrents in Luther's Thought. . . 67

Luther's Church in Retrospect. . . . 69

Conclusion . . . . . . . . . ' 71

SELECTED BIBLIOGRAPHY • • . • • • • • • • • . . • 72 
CHAPTER I

\section{INTRODUCTION}

Martin Luther stood at the vortex of the social, political, and religious storm that marked the birth of the modern world. That he did not cause that storm is certain; the currents of discontent and pressures for change had been growing for generations and were boiling into view through numerous cracks in the feudal order of Europe. But certainly Martin Luther, as much as any other man of his age, left his name and personal imprint on the history of the sixteenth century.

Albert Hyma has said that more has been written about Martin Luther than any other person in history except Jesus Christ. 1 The sheer volume, range, and quality of scholarship that has been devoted to this man should caution and discourage new contributions, especially from a novice. Yet the impact of Luther's genius upon his Church and his age--an impact rooted in his many-sided and controversial personality--is justifiably attractive to a civilization four and one-half centuries later caught in a similar, if more devastating, cultural and social storm.

$1_{\text {Referred to by Edward Gritsch, "Introduction to }}$ Church and Ministry," Luther's Works, 39:xvi. 


\section{THE THESIS QUESTION}

Two complementary elements of a single question coalesce to form the heart of this study. One of these is essentially theological and the other is social; together they form two sides of one aspect of Luther's thought on the meaning and importance of the individual. On the one hand, the theological element concerns his concept of the Church, and seeks to pinpoint the place and role of the average layman in it. His doctrine of the priesthood of all believers and his repudiation of the clerical church of the papal hierarchy implied a new church form in which lay people rather than the priests were the focus. He held that the Church was no more than the assembly of believers in a given locality, and the sum of all such assemblies. Yet the active and passive aspects of the laity's participation in "their" Church are not clear.

The social element, on the other hand, has to do with the question, what can be discovered about Luther's personal attitudes and prejudices toward persons who composed the mass of German society, and who constituted the flesh and blood with which he proposed to build a restored Church. What he saw and felt when dealing directly with people apart from theological abstractions could give much insight into the nature and emphases of his leadership.

These two elements intersect to form this thesis question: Did Luther hold a social prejudice against the lower 
classes and in favor of the upper classes that caused him to modify or reinterpret his concept of the Church in the course of his career?

\section{THE THEORETICAL FRAMEWORK}

It is important to approach the social element through the theological one. Luther was theological to the core; all that he taught, even that of pragmatic and earthy nature and import, was theological at its genesis. On the one hand, it appeared that Luther's teachings were, at least by implication, a condemnation of the injustice and abusiveness of the social structures of his day, and an implicit invitation to and justification for the use of whatever means those who considered themselves oppressed thought necessary to change those structures. This is how the earlier radical leaders like Muntzer and Karlstadt interpreted him. Misunderstanding the thrust of Luther's teaching, they saw in him a national hero and unifying catalyst.

On the other hand, his violent "repudiation" of the cause of the peasants during the Peasants' Revolt of 1525 is often seen as an abrupt about-face as Luther played into the hands of ambitious and greedy princes, becoming their pawn to justify the status quo ante and developing absolutist tendencies. This picture (admittedly overdrawn) of Luther as a "fair-weather" reformer who, upon sticking his toe into the too-warm waters of "real" reformation (i.e., revolution), 
went running back to the safety of the establishment, highly colored the popular conception of him in his lifetime, and influences the twentieth century conception of him through our bias in favor of any group who is oppressed or deprived. The scope, complexity, and controversy that characterizes Luther studies make it difficult if not impossible to find a non-controversial starting point. Therefore, the following judgments are set forth with full realization that each of the four is in some way controversial, and could well form the basis of independent studies in itself. It is not possible within the scope of this paper to give full consideration to them, but they do play a part in the interpretation of the material presented.

First, it can be demonstrated that there is no essential change in the tone of Luther's writings in regard to the common people after the Peasants Revolt of 1525. His harsh stand was taken not because those involved were peasants, but because they had broken divine law and order, an issue that plays an important part in this study.

Secondly, it can also be demonstrated that there is a progression in Luther's writings. This progression is from the young and idealistic Luther to the mature Luther, and from theology and theory of the early years to the problems of life and work in the newly reorganized church of the later years. The doctrine of the priesthood of all believers gave each Christian the same rights and prerogatives 
exclusively on the grounds of the redemptive work of Christ. In practice the idealism present in early writings gives place to a pragmatism, if not a realism, concerning the dispositions and capabilities of the laity. This altered attitude was born in the difficult years of transition. Thirdly, Luther's doctrine of two kingdoms gives rise to a certain ambivalence in his writings that causes him to treat the same person or class very differently in different contexts. A man's role rather than his person or personality is generally the focus of Luther's attention, though the language and emotions of polemics often obscure that fact. Fourthly, there is support for the judgment that Luther formed no solid or continuous alliance with any specific social group, but maintained a tenuous independence from and relationship to all groups, though certainly not equally. A strong and consistent sense of mission and a dogmatic certainty of an imminent Judgment Day prevented him from identifying any particular temporal cause with "the right."

\section{LIMITATIONS AND BOUNDARIES}

In a field of study as vast and complex as Luther studies, certain limitations and boundaries must be established, even though in certain instances they may be somewhat arbitrary.

First, this paper is not intended to be a full or 
exhaustive study of Martin Luther's theology of the Church. Rather, it is limited to the exploration of the relationship between the Church universal and the lay communicants who in his mind formed that Church. Thus theological issues such as monasticism and the clergy, doctrinal issues like the use of the "keys" and apostolic succession, and practical religious matters such as liturgy are mentioned only at points where they may bear on the question at hand.

Secondly, this paper is not a study in depth of the social impact or consciousness of Luther or Lutheranism. Those aspects belong to the realm and methodology of the sociologist.

Thirdly, the author has not attempted to document differences which may exist in Luther's attitudes toward different class levels below the broad division that separated the nobility and the commoners. This does not overlook the vast differences that did exist, for instance, between the peasant and the city guild craftsman or councilman. Rather, it places the accent where Luther himself placed it--on the distinction between the governor and the governed.

\section{METHOD OF PROCEDURE}

To pursue this study in the context and within the limitations already stated, I have adopted the following procedures in relation to primary and secondary sources. As has already been noted, the amount of secondary material 
available is staggering. Therefore I have observed two limitations. First, I have cited only the most significant and relevant secondary works, throwing the main emphasis on Luther's writings themselves.

Secondly, only secondary sources available in English have been used, not because they are necessarily the best or most important, but because of my still inadequate comprehension of German and Latin.

As to Luther's works themselves, those incorporated in the American Edition of Luther's Works ${ }^{2}$ have been used. The titles chosen for study were selected for these reasons: that in them Luther dealt either directly or indirectly with the question at hand, and that the dates of writing the works are spread over his entire career. This selection by both content and date serves to give a broad perspective on Luther's position in specific questions and avoids distortions fostered by certain works written in adverse circumstances or in response to a particular situation.

${ }^{2}$ Luther's Works, ed. by Jaroslav Pelikan and Harold Lehman, 55 vols. (Philiadelphia: Fortress Press and Concordia Publishing House, 1955). 


\section{CHAPTER II}

\section{THE CHRISTIAN IN THE CHURCH}

The Roman Church that Martin Luther vowed to serve as he entered an Augustinian Eremite monastery on $17 \mathrm{July} 1505$ was a monolithic religious system that dictated religious dogma to most of the citizens of European states. Yet its monolithic appearance was deceptive, for under the umbrella of obedience to the pope crowded an assortment of persons, philosophies, doctrines, and practices whose variety staggers the mind. As long as certain foundational doctrines were unquestioned the church could tolerate an amazing diversity of thought and practice. Theological and academic disputations on virtually any aspect of theology or canon law were held as a matter of course and tradition in every university. Even the humanists, with their biting criticism of abuse and neglect in the church, could remain under that umbrella.

This potpourri of conflicting interpretations and decrees found its strength and justification in a doctrine which had for generations been drilled into every man, woman, and child that came under the influence of the church: there is no salvation outside the sacraments of the church. And for the medieval person, that was a very important question, living as he did in an age that, for all its baseness and ignorance, was preoccupied with preparation for the 
hereafter.

The accepted interpretation was that the church existed by divine ordination as the sole purveyor of God's grace to the individual. It came to be identified only with the "spiritual estate"--the priesthood, the orders, and the hierarchy--an ecclesiastical organization in which lay people had no part. On the ecclesiastical front, the development of the papal role as a full-fledged temporal sovereign with all the concomitant political, diplomatic, and military roles eclipsed spiritual concerns and served to vastly increase the distance between the church and the people. On the theological front, the development of the sacrificial interpretation of the mass, with the accompanying doctrines of the indelible character of the priest and sacramental grace, served to make this distance between church and layman an article of faith--it was supposed to be this way.

The Lutheran revolt struck at the foundation of this edifice, denying that the church was the mediator between God and man. For the Christian man was the Church, and he could approach God directly on his own and others' behalf. In this chapter on the nature of the Church in Luther's thought, the discussion will begin with his definition of the Church, then move to the believers' roles and rights in the Church, the nature of Christian freedom, and finally, the place of authority in the Church. 


\section{LUTHER'S DEFINITION OF THE CHURCH}

To discover a concise yet complete definition of the Church from Martin Luther himself is both very simple and exceedingly complex. The simplicity lies in a single theological statement. Luther, in response to this very question, replied, "A seven-year-old child knows what the church is, namely, holy believers and sheep who hear the voice of their shepherd." I

The complexity comes in analyzing the implications of that statement. The relationship between the concepts of the visible versus the invisible Church in Luther's thought has furnished the ground for much discussion and study.

The Invisible Church

In 1521 Luther responded to a vindictive defense of the supremacy of the pope by Jerome Emser with "On the Papacy in Rome, Against the Most Celebrated Romanist in Leipzig." In it he wrote

- . that Christendom means an assembly of all the people on earth who believe in Christ, as we pray in the Creed, "I believe in the Holy spirit, the communion of saints." This community or assembly means all those who live in true faith, hope, and love. Thus the essence, life, and nature of Christendom is not a physical assembly, but an assembly of hearts in one faith, as St. Paul says in Ephesians 4, "One baptism, one faith, one Lord." Accordingly, regardless of whether a thousand miles

lQuoted by Eric Gritsch, ed. and trans., vol. 39, Luther's Works, in "Introduction to Church and Ministry," p. xvi. 
separates them physically, they are still called one assembly in spirit, as long as each preaches, believes, hopes, loves, and lives like the other. ${ }^{2}$

Eighteen years later he wrote, in "On the Councils and the Church," "Thus the 'holy Christian church' is synonymous with a Christian and holy people . . ." 3

To emphasize this concept of community, Luther rejected the use of the word "church" as often as he could, especially in the German New Testament, choosing rather to use such words as "community," "congregation," or "assembly."4 Such terms for him made a clear distinction from the common conception of the church as a quasi-political institution. As Noll emphasizes,

Through whatever words he could find, Luther was determined to eliminate static, parochial, or institutional connotations of the word "church" and to refocus attention on the gathering of individual Christians under the Word of God. ${ }^{5}$

The Visible Church

Luther viewed man as an indivisible unity made up of a physical or material body and an immaterial spirit or soul. He could never differentiate, as some did, between that which was purely spiritual and that which was purely physical. For this reason he could not understand the Anabaptists' teaching on "spiritual worship" (with no religious

$$
\begin{aligned}
& { }^{2} \text { Luther's Works, 39:65. }{ }^{3} \text { Luther's Works, } 41: 144 . \\
& { }^{4} \text { Gritsch, ed., Luther's Works, } 39: x i i i . \\
& { }^{5} \text { Mark A. Noll, "Believer-Priests in the Church: }
\end{aligned}
$$
Luther's View," Christianity Today, October 1973, p. 6. 
ceremony or liturgy), nor their concept of a "spiritual church" (with no external attributes or organization). For him, the Church must have external, visible reality in just the same sense that a man must have an external, visible body. This acceptance of the principle of a visible church was and is the source of the complexity of Luther's definition of the Church. The tension that must always exist between form and content took a major role in the development of the reformed Church as traditional forms were imbued with evangelical content. Eric Gritsch says of this tension:

To him, the church is neither an invisible Platonic reality nor an unchanging institution. Rather, like the individual Christian, the church is continually struggling and constantly recreated and sustained by the word of God. 6

Paul Althus emphasizes that Luther spoke of a group that was recognizable, not invisible, no less real, important, or of less historical reality than Roman Catholicism. 7 Very frequently Luther affirmed that his was the apostolic movement: that the papal church, with its ceremony, pomp, Iuxury, and power, had apostatized from the true church and persecuted it. But that made the true Church no less visible and concrete by comparison. He wrote in 1523 that "the sure mark by which the Christian congregation can be

\section{${ }^{6}$ Luther's Works, p. xvi.}

7Paul Althus, The Theology of Martin Luther (Philadelphia: Fortress press, 1966), trans. Robert C. Schultz, p. 288 . 
recognized is that the pure gospel is preached there." $8 \mathrm{He}$ also said,

Whoever seeks Christ must first find the church. Now the church is not wood and stone but the group of people who believe in Christ. Whoever seeks the church should join himself to them and observe what they teach, pray, and believe. For they certainly have Christ among them. 9

Luther's simple definition of the Church is adequate as an article of faith. Yet it does not address or give clear basis for dealing with the myriad questions that arise when such a definition is applied to a visible group of people within the context of liturgical and ecclesiastical traditions developed over fourteen centuries. It is the old problem of new wine in old wineskins. The Anabaptists sought to solve the problem through the rejection of all tradition; Luther's solution lay in salvaging, cleansing, and refilling the traditions with evangelical faith.

\section{THE BELIEVER-PRIEST}

However widely authorities may differ on the interpretations and implications of Luther's theology, they agree on one point: his rediscovery of the doctrine of the priesthood of the believer was the most revolutionary concept in the history of Christian doctrine. In 1523 Luther

8"That a Christian Assembly or Congregation Has the Right and Power to Judge AlI Teaching and to Call, Appoint, and Dismiss Teachers, Established and Proven by Scripture," Luther's Works, $39: 305$.

9Quoted in Althus, Theology, p. 287. 
wrote the tract "Concerning the Ministry," in which he outlined seven priestly functions that the papal church had stolen from the lay people and given to a "spiritual estate," falsely so called. For the sake of clarity, these are enumerated here in brief form.

1. It is the right of every believer when called upon, to preach the Word.

2. It is his right to administer baptism when the occasion demands.

3. It is his right to administer the Lord's Supper when called upon to do so.

4. The exercise of the keys in binding and loosing (excommunication) is the right of the believer.

5. Only the believer can truly sacrifice, that being his own body as a living sacrifice to God.

6. Every believer may pray for and represent to God any other person.

7. It is his right to judge the validity of doctrine. 10

It would be unnecessarily time-consuming to try to fully document how each of these rights actually functioned in church life. Baptism, the Lord's Supper, and excommunication will be studied in some detail in Chapter Four. In relation to the discussion at hand, these three generally

${ }^{10}$ Luther's Works, $40: 21-32$. 
fell into the same category as the ministry of the Word. The right to sacrifice is the only one of the list that is purely a personal matter between the believer and God, and is not particularly relevant to this discussion.

The Ministry of the Word

The priesthood of the believer revolved on Luther's concept of the Word of God as an active agent in the hearts of men. Noll summarizes this role of the Word in the believer:

- . The Christian has more than the bare word of Scripture, said Luther: he has that word quickened in his hearing until it becomes the voice of his Shepherd, the very Word of God himself .. . It is this living Word in a believer that creates a priest of God, that equips the Christian for a life of service to God. - . Luther described Christians as ones "inwardly taught by God" and as having "God's word... on their side.". . . Luther could boldly state: "Therefore, when we grant the Word to anyone, we cannot deny anything to him pertaining to the exercise of his priesthood. . "II

Luther believed that in baptism the believer was consecrated a priest, and that in the hearing of the Word faith was born. Every believer had equal access to God and the ministry of the Holy Spirit. The Word, and therefore the ministry of the Word, belonged by right to every Christian equally. But at this point Luther and the radicals met head on, for he insisted that though every believer was by right a preacher, the exercise of that right must be private. He wrote that ". . . we must act according to Scripture and call 
and institute from among ourselves those who are found to be qualified and whom God has enlightened with reason and endowed with gifts to do so to preach publicly."12 Expanding on this instruction, he wrote:

First, if he [the Christian] is in a place where there are no Christians he needs no other call [to preach or teach] than to be a Christian, called and anointed by God from within.

Secondly, if he is at a place where there are Christians who have the same right and power as he, he should not draw attention to himself. Instead, he should let himself be called and chosen to preach and to teach in the place of and by the command of the others. 13

The distinction between the public and private ministry and priesthood is a critically important point in Luther's thought. It has major bearing on the layman's relation to his church, for the primary rights of priesthood still were exercised by a selected group. Luther felt that there was practical as well as theological justification for this position. In 1532 he wrote a tract against "Infiltrating and Clandestine Preachers," aimed, of course, at the Anabaptists. In discussing the practice of the early church in having several prophets or preachers speak from their place among the members of the congregation in an informal manner, he said, "It would hardly do to restore this practice among such uncouth, undisciplined, shameless people as ours."14

12 "Christian Assembly," Luther's Works, $39: 309$. 13 Ibid., p. 310 . ${ }^{14}$ Luther's Works, $40: 393$. 
This fear of public disorder is an important theme which will be mentioned later.

The Ministry of Absolution

Nowhere is Luther truer to his theology than in his teaching on absolution. Penance was the last of Rome's five additional sacraments that Luther discarded. He gave great significance to the word of forgiveness when spoken by a Christian, whether minister or brother. In his address "To the Christian Nobility of the German Nation Concerning the Reform of the Christian Estate" he advised:

. . If your superiors are unwilling to permit you to confess your secret sins to whom you choose, then take them to your brother or sister, whomever you like, and be absolved and comforted. Then go and do what ever you want and ought to do. Only believe firmly that you are absolved, and nothing more is needed. 15

Two years later he wrote:

This means that I may go to my good friend and say to him, "Dear friend, this is the trouble and the difficulty which I am having with sin," and he should be free to say to me, "Your sins are forgiven, go in the peace of God." You should absolutely believe that your sins are forgiven as though Christ himself were your father confessor--as long as your friend does this in the name of God.16

In this area of priesthood in particular, but in all the other areas to one degree or another, Luther envisioned a quality of relationship between the members of the Church that was deeply intimate and loving. This mutual confession,

${ }^{15}$ Luther's Works, $44: 180$.

16 Quoted in Noll, "Believer-Priests," p. 6. 
forgiveness, and support under the authority of the Word of God was a relationship that he himself deeply desired. Yet the ignorance, crudeness, and insensitivity that he felt characterized the people made that quality of relationship impossible at the present, and he structured the Church to prevent those qualities from tainting the public ministry of the Church.

The Ministry of Judging Doctrine

Probably no area of priesthood was as delicate for Luther as the right to judge the validity of doctrine. Understandably, it is the area that was modified the most in the course of his career. In 1523 he wrote,

Here you see clearly [John $10: 4,5,8]$ who has the right to judge doctrine: bishops, popes, scholars, and everyone else have the power to teach, but it is the sheep who are to judge whether they speak the voice $i . e_{i}$, the words of Christ or the voice of strangers. $17^{2}$

Yet it was only nine years later that he wrote, in opposition to the Anabaptists,

Thus we read in St. Paul: "Let two or three prophets speak, and let the others weigh what is said," etc. This of course is said only of the prophets, and of which ones should speak and which should weigh what was said. What is meant by "others"? The people? of course not. It means the other prophets or those speaking with tongues who should help in the church with preaching and building up of the congregation, those who should judge and assist in seeing to it that the preaching is right. 18

17"Christian Assembly," Luther's Works, 39:307. 18"Infiltrating Preachers," Luther's Works, 40:392. 
Once again, a basic distrust of the capabilities and sensitivity of the people is evident. In Chapter Four this basic attitude will be more fully explored. The irony of the situation is that the radicals, though justly faulted in many aspects of theology and practice, in the area of the practice of priesthood succeeded in coming far closer to Luther's own ideal of the quality of life and relationship in the Church.

III. THE FREEDOM OF THE CHRISTIAN

Against the background of the seemingly infinite list of requirements and restrictions in the religious practice of the Roman Church, Luther's proclamation of the freedom of the Christian was attractive indeed. Yet grave injustice was done to Luther's position in his life time by failing to observe or ignoring the limitations that he placed on it. His paradoxical statements are well known:

A Christian is a perfectly free lord of all, subject to none.

A Christian is a perfectly dutiful servant of all, subject to all. 19

In contrast to the concept of freedom held by the radical peasants and most people today as well, Christian freedom for Luther was not an individualistic concept. If the two statements could be condensed further without violating their intent, the new statement might read, "The

19"The Freedom of a Christian," Luther's Works, 31:344. 
Christian is free to serve," or perhaps more accurately, "The Christian is free in serving." The good works which were to characterize the communio sanctorum were not the fulfillment of legal requirements or in any way attempts to merit God's favor. They were to be totally free gifts of love to brothers and sisters. 20 The freedom is absolute, in that there was no requirement, whether legal, moral, or ceremonial, which any believer had to add to his faith in order to be justified. Yet the very realization and consciousness of justification solely through faith so humbled the believer that he would gladly and freely give himself in service to his fellow believers and all other persons in his world of experience. Luther explains himself;

- . With respect to the kingship, every Christian is by faith so exalted above all things that, by virtue of a spiritual power, he is lord of all things without exception, so that nothing can do him any harm. As a matter of fact, all things are made subject to him and are compelied to serve him in obtaining salvation. . This is not to say that every Christian is placed over all things to have and control them by physical power. .

The power of which we speak is spiritual. It rules in the midst of enemies and is powerful in the midst of oppression. This means nothing else than that "power is made perfect in weakness" and that in all things I can find profit toward salvation, so that the cross and death itself are compelled to serye me and to work together with me for my salvation. 2

Only deliberate misrepresentation or blind presupposition could force these statements to refer to or imply social

20Althus, Theology, Pp. 300-302.

21"Freedom of a Christian," Luther's Works, 31:354-355. 
or political freedom. In fact, in reply to one of the twelve articles of the peasants in 1525 Luther said,

This article would make all men equal and so change the spiritual kingdom of Christ into an external worldly one. Impossible! An earthly kingdom cannot exist without inequality of persons. Some must be free, others serfs, some rulers, others subjects.22

Luther's position on the relationship of the Christian to the temporal authority will be discussed in the next chapter.

\section{AUTHORITY IN THE CHURCH}

Luther's position that the Christian assemblies of each community had the right to determine their own affairs and to choose their own ministers greatly complicated the development of a cohesive and recognized general leadership in the church. He himself, as spiritual leader and advisor, filled part of the need. Yet he could not meet the administrative needs of the church for two reasons. First, his own temperament and personality were not suited to that work, and this he recognized. He viewed himself as a theologian and university professor, not as an organizer and administrator. Secondly, being under the ban of the Empire and an outlaw for most of his career, he could not travel freely or widely, and certainly not beyond the domain of Elector Frederick the Wise of Saxony. Yet he was keenly aware of the need for leadership and mentioned it frequently. This

22"Admonition to Peace, A Reply to the Twelve Articles of the Peasants of Swabia, Luther's Works, 46:39. 
section is concerned with the theoretical position of the bishop and the pastor, while the actual development of these offices will be discussed in Chapter Four, in connection with the rise of the territorial church.

\section{The Bishop or Superintendent}

The ideal bishop or superintendent that Luther envisioned for the church in Germany was one patterned on the Scriptural model of Paul and Timothy. Luther's bishop was to be a pastor of pastors--one who through love and persuasion, without force or threat, would lead his flock in preaching the evangelical gospel. All such men were equals; no one bishop could be or should be supreme, and each was to consider himself as no more than the equal of the poorest laborer who believed the gospel.23 "The Instructions for the Visitors of Parish Pastors in Electoral Saxony," written in 1528, is actually the work of Philip Melanchthon, but had a preface by Luther and is considered to be the expression of his thought. In it is this description of the work of the superintendent.

He shall make sure that in these parishes there is correct Christian teaching, that the Word of God and the holy gospel are truly and purely proclaimed, and that the holy sacraments according to the institution of Christ are provided to the blessing of the people. . . If one or more of the pastors or preachers is guilty of error in this or that respect, the superintendent shall call to himself those concerned and have them abstain from it, but also carefully instruct them wherein they are guilty and have

23"On the Papacy in Rome," Luther's Works, 39:74. 
erred either in commission or omission, either in doctrine or life. But if such a one will not then leave off or desist, especially if it leads to false teaching or sedition, then the superintendent shall report this immediately to the proper official who will then bring it to the knowledge of our gracious lord, the Elector. His Electoral grace will then be able in good time to give this proper attention. 24

Even this excerpt demonstrates a somewhat modified view of the authority of the bishop. Five years earlier Luther wrote, in reference to the problem of false doctrine:

Again you say, "The temporal power is not forcing men to believe: it is simply seeing to it externaliy that no one deceives the people by false doctrine; how could heretics otherwise be restrained?" Answer: This the bishops should do; it is a function entrusted to them and not to the princes. Heresy can never be restrained by force. One will have to tackle the problem in some other way, for heresy must be opposed and dealt with othervise than with the sword. 25

This shift, as later discussion will show, stemmed from the absence of such administrative leadership in the Lutheran movement, and the coolness of the lower classes to Lutheran teaching, with an accompanying disposition to be influenced by radical theology. It boils down to the fact that Lutheranism at its beginning did not have the means within itself to exercise authority in the issue of false doctrine, a fact that had clear repercussions in the later development of the church. Luther perhaps unconsciously

\section{Luther's Works, $40: 313$.}

25"Temporal Authority: To What Extent it Should be Obeyed," Luther's Works, $45: 114$. 
felt that this was the work of the Holy Spirit, but the presence of a majority of non-believers included in the church through the parish system made the leadership of the Spirit through the Word a theological impossibility.

\section{The Pastor}

The first practical problem that Luther had to deal with as the Reformation spread was the securing of pastoral leadership for evangelical congregations. As early as 1520 in his address "To the Christian Nobility," Luther counseled,

So then, we clearly learn from the Apostle that it should be the custom for every town to choose from among the congregation a learned and pious citizen, entrust to him the office of the ministry, and support him at the expense of the congregation. He should be free to marry or not. He should have several priests or deacons, also free to marry or not as they choose, to help him minister to the congregation and community with word and sacrament. .26

On the relation of the person so chosen to the members of the congregation, Luther said,

Therefore, when a bishop consecrates it is nothing else than that in the place and stead of the whole community, all of whom have like power, he takes a person and charges him to exercise this power on behalf of the others. It is like ten brothers, all king's sons and equal heirs, choosing one of themselves to rule the inheritance in the interests of all. In one sense they are all kings and of equal power, and yet one of them is charged with the responsibility of ruling. 27

Throughout his career Luther gave increasing importance

${ }^{26}$ Luther's Works, $40: 175$.

27Ibid., p. 128 . 
to the call and commission of the pastor. The public character of this call was especially significant in combatting the Anabaptist preachers of whom he wrote in 1532:

Even if these infiltrators were otherwise faultless and saintly through and through, still this one fact (that they sneak about unbidden and uncommissioned) sufficiently proves that they are the devil's messengers and teachers. For the Holy Spirit does not come with stealth. 28

Lutheranism no doubt inherited a large part of its parish ministers from the ranks of the Roman lower clergy, who as a class were notoriously uneducated. Yet it was to these men as a class that Luther gave the responsibility for the proclamation of the gospel and the ultimate success of evangelical reform. In 1520 in his exposition of the "Sermon on the Mount" Luther gave the designations "salt of the earth" and "light of the world" to the pastors alone. 29 To aid and help them, he wrote numerous books of sermons, which they could read if nothing more, as well as German liturgy and hymns, and educational guides. For him, to education and edify them was to do the same for the congregation.

$$
\begin{aligned}
& \text { 28"Infiltrating Preachers," Luther's Works, 40:384. } \\
& \text { 29Luther's Works, 21:54-58. }
\end{aligned}
$$




\section{THE CHRISTIAN IN THE WORLD}

The ethical relationship of a man's religion to his conduct is perhaps the thorniest problem that philosophers or theologians must tackle. This is of preeminent significance in Christianity because of the high and stringent ethical demands of Scripture, from the Ten Commandments to the Sermon on the Mount. Martin Luther's solution to this dilemma was in the formulation of what has come to be called "the doctrine of the two kingdoms." Characteristically, Luther developed this area of thought in response to problems in understanding the nature and operation of justification by faith, and the justified man's life of continuing sanctification. Nowhere did Luther develop the doctrine logically and completely--it comes out in "bits and pieces" in response to various questions in many contexts. In doing so, he seems to apply the doctrine to many different, though related, dualisms, such as the kingdom of Christ and the kingdom of the world, the kingdom of God and the kingdom of Satan, or the spiritual church and the external church. The result is a great deal of controversy as to his specific meanings and applications.

The purpose of this chapter is not to give a complete analysis of the doctrine of the two kingdoms. Rather, the 
purpose is to find an adequate understanding of the doctrine in more or less general terms as it applies to three issues. First, how is the Christian layman to regard the authority of government? Secondly, how is the Christian layman in government, whether prince or officer, to regard his place? And thirdly, what was Luther's frame of reference in his reaction to civil disturbance, notably, the Peasants War of $1525 ?$

Luther's doctrine of the two kingdoms was aimed at a dual perversion of governmental power that had developed in medieval society. First, the bishops and other prelates had left the spiritual care of souls to rule temporal estates, provinces, or states, and had surrounded themselves with such pomp and luxury that the temporal lords were hard put to keep up. Secondly, the temporal rulers neglected their God-given responsibility of governing and protecting their subjects. Instead, they merely exploited them for their own gain, and at the same time wished to have spiritual rule over their souls, enforcing the observance of Roman Catholicism by force. Thus, said Luther, "they neatly put the shoe on the wrong foot: They rule the souls with iron and the bodies with letters."I

Professor Bornkamm gives an important perspective for understanding Luther's frame of reference for the development of this doctrine.

1"Temporal Authority," Luther's Works, 45:109. 
- . Luther did not formulate the question of the relation of the church to the world as that of one institution to another (the state). This he could not do either in the medieval sense, since he did not acknowledge the church to be a separate, hierarchical legal body, or in the modern sense, for he was not acquainted with the distinction between the civil and ecclesiastical communities based on their differing constituencies. His placement between these two epochs helped Luther to go to the root of the question: the relation of the Christian to the world. 2

In this chapter the doctrine of the two kingdoms will be discussed under several headings, then the place of the Christian in the world will be analyzed as to obedience, suffering, and participation in government.

\section{LUTHER'S TWO KINGDOMS}

God's "Invisible Kingdom"

The two kingdoms doctrine necessarily has its tap root in Luther's basic conception of God as the absolute sovereign of the universe. God is actively involved in the maintenance of all creation: He is a God of active omnipotence.

This we assert and contend, that God, when He acts this side of the grace of the spirit, works all things, even in the impious, for He alone who created all things, by Himself moves all things, guides them, and propels them by the omnipotence of His motion. . . Then, when He acts with the grace of the spirit in them, whom He justifies, that is, in His Kingdom, He guides and moves them similarly with His omnipotence, and they, as they are the new creature, follow and

2Heinrich Bornkamm, Luther's Doctrine of the Two Kingdoms, trans. Karl H. Hertz, Quoted in Social Ethics series, No. 14, Gen. ed. Franklin Sherman (Philadelphia: Fortress Press Facet Books, 1966), p. 13. 
cooperate or rather, as Paul says, they suffer His action. . . 3

The basic unity of the two kingdoms as expressions of divine will and presence rather than impersonal instruments is an important key in analyzing the doctrine. Yet the fact of the existence of this unity is not obvious or even visible to natural reason, but must be maintained as an article of faith.

\section{The Two Kingdoms}

Luther used the two terms "kingdom" and "government" in referring to this doctrine, and at times he appears to use them interchangeably. However, as Professor Bornkamm points out, there is a distinction between them, though it is not consistently maintained. The "kingdom" refers to the realm of lordship, while "government" refers to the mode or method of lordship. 4 The terms are inseparable, and the meanings often interpenetrate one another. Since this study is concerned with the practical results of the doctrine more than its internal nuances, the term "kingdom" will be used unless the context clearly requires the other.

Professor Bornkamm also notes that the frame of reference in which the doctrine was developed was three dimensional. First, it addressed the relationship between the

${ }^{3}$ F. Edward Cranz, An Essay on the Development of Luther's Thought on Justice, Law, and Society, Harvard Theological Studies, no. 19 (Cambridge: Harvard University Press, 1964), p. 166.

4Two Kingdoms, p. 17. 
medieval church and state that was described earlier as "the shoe on the wrong foot." 5 Secondly, it addressed the general relationship between the spiritual and the secular, the kingdom of Christ and the kingdom of the world. Thirdly, it addressed the activity of the Christian in his own behalf and in behalf of others. This dimensional aspect becomes important, for instance, in the questions of boundaries. The boundary between church and state (first dimension) is clear and open, while the boundary between self and others (third dimension) is inward and hidden. 6

Luther held that there were two realms in which the Christian man lived. In Christ through faith, and thus in the Church, he was bound by no authority but that of the law of love. His conscience was free: he could not be forced to accept any particular form of doctrine or practice--he voluntarily followed the Holy Spirit operating inwardly through the Word. At the same time he lived in the world and was subject to temporal authorities. In this realm he was entirely submissive to the authorities, even when obedience involved personal loss and suffering.

This does not imply that a man is part free and part bound, or part spiritual and part temporal, for this dichotomy violates Luther's basic concept of man as a unity. The development of Luther's thought at this point has been

\footnotetext{
5 See page 27.

${ }^{6}$ Two Kingdoms, p. 16.
} 
carefully documented by Professor Cranz. He writes:

- . At the point of Luther's ultimate concern, in their relation to the Christian's existence, the dualisms of the 1513-18 period refer to the two parts of man; he is partly carnal and partly spiritual, partly attached to things visible, and partly to things invisible. On the other hand, the dualisms of the 1530's apply to the "whole" man. The Christian, and not simply part of him, exists in the realm of reason; the Christian and not just part of him, exists in the realm of grace. But is the Christian then dichotomized into two separate and unrelated whole men? No, because Luther will

finally say that these two "existences" are only two "persons" both borne by the single Christian individual. The relevant analogy is not that of parts and a whole but of Christ who is perfect God and perfect man, two natures in one person.?

As Professor Bornkamm writes,

Everything depends on grasping that we are not dealing with a tearing asunder of the world into two rigidly separated realms, but with a question of perspectives; it is one and the same world, but seen from two different viewpoints, "for me--for others," which the Christian must always choose between in making fresh and living decisions. 8

That is a summary of some initial aspects of the two kingdoms doctrine from the perspective of the Christian man. From the viewpoint of the unbelieving "worldly" man other aspects are evident.

In 1526 Luther wrote:

God has established two kinds of government among men, one which is spiritual through the word without the sword, by which men should become pious and just.. - and another worldly government through the sword, so that those who do not wish to become pious through the word for eternal life, should

7Justice, Law, and Society, P. 62 .

BTwo Kingdoms, p. 14. 
nevertheless be forced through the world government to be just for the world. 9

In his tract "Temporal Authority" Luther contrasted the Christian and the non-believer:

If all the world were composed of real Christians, that is, true believers, there would be no need for or benefits from prince, king, lord, sword, or law . . . It is because the righteous man of his own accord does all and more than the law demands. But the unrighteous do nothing that the law demands; therefore, they need the law to instruct, constrain, and compel them to do good. 10

And at another time he wrote,

Earthly government is a glorious ordinance of God and a splendid gift of God, who has established and instituted it and will have it maintained as something that men cannot do without. If there were no worldly government no man could live because of other men: one would devour the other, as the brute beasts do... so it is the function and honour of earthly government to make men out of wild beasts and to prevent men from becoming wild beasts. . 11

The non-believing man had to have coercive government in order to live in a remotely civilized manner, according to Luther. Its importance is emphasized both by his firm belief that "the world and the masses are and always will be un-Christian, even if they are all baptized and Christian in name," 12 and by the complementary persuasion that man's total depravity prevented the possibility of anything good coming

${ }^{9}$ Quoted in Cranz, Justice, Law, and Society, p. 169. 10 Luther's Works, 45 :

11Quoted by Gordon Rupp, The Righteousness of God (London: Hodder and Stoughton, 1953), p. 293.

12 "Temporal Authority," Luther's Works, 45:91. 
from his will. The aspects of Luther's attitude toward the people that have been and will be brought out in this study are highly colored by a theological as well as a social justification.

\section{OBEDIENCE AND ORDER}

Obedience was the crowning virtue of the Christian's relationship to the kingdom of the world as far as Luther was concerned. The very fact that by faith the Christian knew that God was just as truly working His will in the secular authority of the prince as in the spiritual leadership of the Spirit in the Word made obedience to the prince essentially the same as obedience to God. By the same token, disobedience to the prince was rebellion against God, with all the theological ramifications that such disobedience presented.

Very early in his career as a monk evidence shows that Luther placed extreme importance on obedience--obedience that called for an extreme and almost fatal asceticism. Even after arriving at the basic elements of evangelical faith and justification, his belief in the God-ordained character of authority was the basis of real spiritual agony for him, as "his own conscience charged him with going against accredited authority and bringing disorder and chaos into Christendom."13 Numerous attempts have been made to

13Rupp, Righteousness of God, p. 301 . 
use this emphasis on order and obedience as the starting point for psychoanalytical studies of Luther. 14 However much Luther was influenced by his relationship with his father, the weight of evidence indicates that that influence is not an adequate foundation for Luther's position. Rather, there is a genuine and rational theological basis.

Luther made one essential and significant exception to the command to obey the civil authorities. That exception is the heart of the two kingdoms doctrine. In "Temporal Authority" he wrote, "The temporal government has law which extend no farther than to life and property and external affairs on earth, for God cannot and will not permit anyone but himself to rule over the soul."15 In the "Instructions to the visitors" the exception is clearly stated:

Every secular authority is to be obeyed not because it sets up a new service to God but because it makes for orderly life in peace and love. Therefore it is to be obeyed in everything except when it commands what is contrary to the law of God, for example, if the government ordered us to disregard the gospel or some of its parts.16

Luther viewed that exception not as an alternative course of action, but the only course of action for the Christian. He referred to those Christians who lived in certain districts where the authorities had ordered the surrender of German New Testaments in "Temporal Authority":

${ }^{14}$ See ibid., p. 85, n. 2, and Erik Erikson, Young Man Luther (New York: W. W. Norton \& Co., 1958).

${ }^{15}$ Luther's Works, $45: 105$.

${ }^{16}$ Luther's Works, $40: 299$. 
They should not turn in a single page, not even a letter, on pain of losing their salvation. Thoever does so is delivering Christ up into the hands of Herod, for these tyrants act as murderers of Christ just like Herod. If their homes are ordered searched and books or property taken by force, they should suffer it to be done. Outrage is not to be resisted but endured: yet we should not sanction it, or lift a little finger to conform, or obey. 17

Perhaps the most succinct statement that Luther made on this issue was in 1521, to Jerome Emser: "I do not desire to be free of human laws and teachings. I only desire to have the conscience free. . ."18

Much has already been said and implied about the importance of obedience for the non-Christian person. For Luther, the only thing which stood between the world and utter and complete anarchy was the obedience (enforced, if necessary) of the people to the civil government. This conviction shows clearly from this excerpt from his book against the Anabaptists and Dr. Karlstadt in particular:

We read . . . in Moses (Exod. 18) that he appointed chiefs, magistrates, and temporal authority before he gave the law, and in many places he teaches: One is to try, judge, and punish in all cases with justice, witnesses, and in an orderly way. Otherwise, why have judges and sovereigns in the land? Karlstadt always skips over this matter altogether too easily. What Moses commands Karlstadt applies to the disorderly masses and teaches them to break into this field in disorder like pigs. This certainly is and must be called a seditious and rebellious spirit, which despises authority and itself behaves wantonly

17Luther's Works, $45: 112$.

18"Answer to the Hyperchristian, Hyperspiritual, and Hyperlearned Book by Goat Emser in Leipzig--Including Some Thoughts Regarding His Companion, the Fool Murner," Luther's Works, $39: 202$. 
as though it were lord in the land and above the law. Where one permits the masses without authority to break images, one must also permit anyone to proceed to kill adulterers, murderers, and disobedient, etc. For God commanded the people of Israel to kili these just as much as to put away images. Oh, what sort of business and government that would turn out to be: 19

In referring to the peasant unrest that characterized sixteenth-century Germany and eventually culminated in the Peasants' War of 1525 , Luther wrote in 1522 ,

I am and always will be on the side of those against whom insurrection is directed, no matter how unjust their cause; I am opposed to those who rise in insurrection, no matter how just their cause, because there can be no insurrection without hurting the innocent and shedding their blood. . . Now insurrection is nothing else than being one's own judge and avenger, and that is something God cannot tolerate. Therefore, insurrection cannot help but make matters much worse, because it is contrary to God; God is not on the side of insurrection. 20

Obedience was absolutely necessary to order; order in all things was ordained by God: thus disobedience and disorder were direct rebellion against the government of God, and, as a later section will present, the responsibility of civil government is to maintain order and enforce obedience.

\section{OBEDIENCE AND SUFFERING}

Several references have already been made concerning the Christian's acceptance of suffering as a result of his

19 "Against the Heavenly Prophets in the Matter of Images and Sacraments," Luther's Works, 40:89.

20 "A Sincere Admonition by Martin Luther to All Christians to Guard Against Insurrection and Rebeliion," Luther's Works, $45: 83$. 
obedience to the temporal authorities. It is not necessary to recapitulate these. It will be sufficient to emphasize that Luther did believe that suffering was the lot of every true Christian living in the realm of the world, and that accepting this suffering in love and responding to one's enemies with good works is the most Christ-like spirit that a man can display. Nor is this suffering merely incidental; it is the direct result of the Christian's way of life. In the sermons on "The Sermon on the Mount" Luther wrote:

So far we have been treating almost all the elements of a Christian's way of life and the spiritual fruits under two headings: first, that in his own person he is poor, troubled, miserable, needy, and hungry; second, that in relation to others he is a useful, kind, merciful, and peaceable man, who does nothing but good works. Now He adds the last: how he fares in all this. Although he is full of good works, even toward his enemies and rascals, for all this he must get this reward from the world: He is persecuted and runs the risk of losing his body, his life, and everything. 21

Going back to the doctrine of the two kingdoms, Professor Bornkamm emphasizes this aspect. The Christian has this hidden boundary that separates the two kingdoms in his life. On one side, in matters concerning himself and his affairs, he must forego force, law, and coercion; he must do good and endure injustice. On the other side of the line, as a member of the kingdom of the world, where the injustice is done to a neighbor or community, he must fight with all appropriate means as an expression of love.22 That

21 Luther's Works, $21: 45$.

22 Bornkamm, Two Kingdoms, p. 7. 
boundary is never arbitrary nor is it apparent to another person, not even another Christian. It is not even apparent to the Christian himself, for he must find it day by day in each new decision and experience that he faces. And by all means, if he is uncertain as to his own position or motivation in a given situation, he must submit rather than run the risk of inadvertently taking up his own defense. In a specific application of this position, Luther resented the peasants calling their cause a "Christian" cause. The very fact that they would publish demands was against Christ's command, and to include in those demands a thinly veiled threat of violence to reach their goals was practically the same as open rebellion against God. Had they presented their cause under any other banner than Christianity, Luther might have responded somewhat differently, at least in certain issues.

\section{THE UNJUST RULER}

It would appear at first that Luther left no recourse to the person, Christian or not, who found himself under the domination of an unjust ruler. Yet that is far from the actual case, for he had the firmest conviction that God was in fact in control, and ordained and deposed governments at His will.

Luther counseled the Christian to remember that there was a difference between the man and his office, and that 
even though the man was evil, he must be respected and obeyed because of his office. An excerpt from the "Instructions to the visitors" reads:

When in Rom. $13 \mathrm{Paul}$ says that the government is of God, this is not to be understood in the sense that government is an affliction in the way that murder or any other crime is inflicted by God, but in the sense that government is a special ordinance and function of God, just as the sun is a creature of God or marriage is established by God. An evil man who takes a wife with evil intent can abuse the ordinance of God. . The ordinance, by which peace and justice is maintained, remains a divine creation even $i f$ the person who abuses the ordinance does wrong. 23

In light of these convictions, the following three steps which he counsels such an oppressed person to take constitute positive and direct action, but in quite a different direction than rebellion:

First, you are to acknowledge your own sins, because of which the strict justice of God has plagued you with this anti-Christian regime. . .

You should in all humility pray against the papal regime. .

You are to let your mouth become such a mouth of the Spirit of Christ as St. Paul speaks of in the text quoted above II Thess. 2:8 .24

Nowhere does Luther equate silence with submission to authority. On the contrary, the preaching of the Word was the Christian's primary weapon in the battle against injustice and oppression. At the very least this means that the Christian is to articulate the reason for his submission and

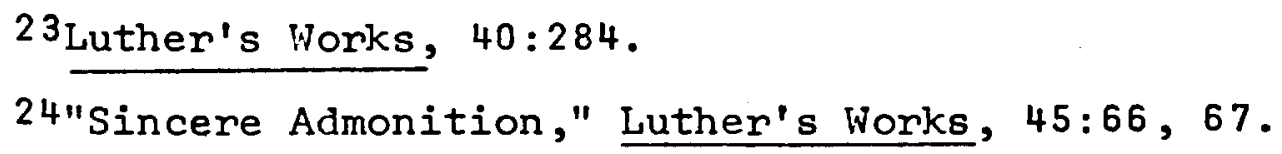


proclaim God's condemnation on injustice, all the while praying for and doing good to his enemy. 25

Professor Rupp summarizes Luther's points made in "Can Soldiers Be Christians?" First, "Tyrants cannot injure the soul,' but are only injuring their own: 'do you not think that you are already sufficiently revenged upon them?'" Secondly, there is something worse than an unjust ruler: "'A wicked tyrant is more tolerable than a bad war.'" Next, "God is at hand and he is able to deal with tyrants." Fourthly, "Since most men were not Christians there was the probability that other subjects would rise in revolt." And fifthly, "God could raise up other rulers to make war on the tyrant." 26

It is worth stating again that such submission is not appropriate where questions of conscience are involved. Numerous incidents can be gleaned from Luther's writings that indicate the scope of "questions of conscience." There is the command to surrender Bibles, already mentioned.27 A preacher is not to refrain from condemning the unrighteous conduct of his lord, even if commanded to stop, or deposed for doing so. And a soldier must refuse to serve his lord in a manifestly unjust war, even at the risk of his property or life.28 The theme is familiar, yet it is a far cry from Luther's position to make issues of social equality matters

$$
\begin{aligned}
& { }^{25} \text { Righteousness of God, p. } 304 . \quad 26 \mathrm{Ibid}, \text { p. } 303 . \\
& 27 \text { See p. 33. } 28_{\text {Rupp }}, \text { Righteousness of God, p. } 304 .
\end{aligned}
$$


of conscience, as did some of his contemporaries and many since then.

\section{THE CHRISTIAN'S ROLE IN GOVERNMENT}

The doctrine of the two kingdoms made it possible for Luther to justify and even encourage Christians who were also officers in or heads of governments. He was fully conscious of the dilemma in which they found themselves, and several statements have already been quoted and referred to which deal with the question of injustice to one's self and one's neighbor. In "Temporal Authority" he writes:

Just as he [the true Christian] performs all other works of love which he himself does not need--he does not visit the sick in order that he himself may be made well, or feed others because he himself needs food--so he serves the governing authority not because he needs it but for the sake of others, that they may be protected and that the wicked may not become worse. 29

Later in the same book he said,

If the governing authority and its sword are a divine service, as was proved above, then everything that is essential for the authority's bearing of the sword must also be divine service. 30

He counseled the Christian,

Therefore if you see that there is a lack of hangmen, constables, judges, lords, or princes, and you find that you are qualified, you should offer your services and seek the position, that essential government authority may not be despised and become enfeebled or perish. 31

And he gives one additional bit of explanation:

$$
\begin{aligned}
& { }^{29} \text { Luther's Works, } \\
& \text { 31Ibid., p. } 95: 94 .
\end{aligned}
$$


. . When such duties are performed not with the intention of seeking one's own ends but only of helping to maintain the laws there is no peril in them. . . for as was said, love of neighbour seeks not its own, how great or small, but considers how profitable and needful for neighbour and community such works are. 32

Luther clearly saw the need for Christians to be in places of leadership in the kingdom of the world, and was especially interested in seeing princes who called themselves Christian act as Christians. Professor Rupp lists the four guiding principles that Luther lays down in "Temporal Authority":

1. He must seek his inspiration from God.

2. He must seek the good of his subjects before his own.

3. He must not allow his sense of equity to be obliterated by the lawyers.

4. He must punish evil-doers with measured severity. 33

Yet Luther was not counseling these rulers and officials to rule according to Christian law in love, 34 for evildoers will respond only to the sword, and the prince or magistrate is not to wield it in vain. Their administration must be thorough but fair, consistent, yet merciful, and have as its primary purpose the maintenance of order and suppression of disobedience and rebellion. He constantly reminded them that their roles as princes and Christians

32 Quoted in Rupp, Righteousness of God, P. 297. 33Ibid., p. 306 . 34"Temporal Authority," Luther's Works, 45:91. 
were in one sense contradictory. 35 In the "Letter to the Princes of Saxony Concerning the Rebellious Spirit," Luther wrote:

Your obligation and duty to maintain order requires you to guard against such mischief and to prevent rebellion. Your Graces know very well that your power and earthly authority are given you by God in that you have been bidden to preserve the peace and to punish the wrongdoer. . . For God will want and require an answer if the power of the sword is carelessiy used or regarded. Nor would your Graces be able to give account to the people or the world if you tolerated violence and rebellion. 36

The prince was a prince, not because he was a Christian, but because God had ordained him to bear the sword for the control of evil. He was a Christian, not because he was a prince, but solely through faith in exactly the same way as any of his subjects. In the tension between these two "persons" that every Christian bore, whether prince or peasant, lay Luther's solution to the problem of the Christian in the world.

35 "Sermon on the Mount," Luther's Works, 21:170. ${ }^{36}$ Luther's Works, $40: 51,52$. 


\section{CHAPTER IV}

THE CHURCH IN THE WORLD

Two facts about Martin Luther's concept of the Church have been established in Chapter II. First, the Church is essentially a spiritual organism in which all true believers are equal members. Secondly, the Church is not an invisible Platonic ideal, but a visible body of Christians characterized primarily by the preaching of the true gospel. These principles take on greater depth and importance as they are set in the context of Luther's doctrine of the two kingdoms .

For Luther, the Church necessarily existed in two realms--the spiritual and the temporal--just as does the Christian man. The relationship goes even further. The Church existed in two realms because the Christian lives in two realms. This is true because the Church is the divine union which unites all Christians living in the two kingdoms. Professor Cranz writes of this dual existence of the Church:

\footnotetext{
- Luther will never limit the title "church"
to this alone [the primary aspect of a spiritual, holy Church], for there is also an external church, which is not properly another church but rather another mode of existence, in the world and in the flesh, of the one true church.l
}

1Justice, Law, and Society, P. 36-37. 
As in the situation of the Christian man, this is not a case of being partly holy and partly earthly and sinful. Rather, the Church is wholly righteous and wholly sinful when seen from different perspectives. As it exists with Christ in God, it is holy, and as it simultaneously exists visibly as part of the world system, it is sinful. One of Luther's statements on this paradox reads almost like a riddle:

The church is such an assembly that we could not comprehend it unless the Holy spirit revealed it. The church is in the flesh and appears as visible; it is in the world and appears in the world. Nevertheless it is not the world nor in the world, and no one sees it. Therefore those who do not proceed in the proper meaning of the words are easily deceived. 2

Luther frequently emphasized that the nature of the two kingdoms, whether regarding the individual or the Church, is not a tenet reached through reason or philosophy, but through revelation, and thus an article of faith not limited to rational comprehension.

Having a visible existence in the world, the Church necessarily had a position related to the social and political structures of the world. To explain these relationships, Luther developed what has come to be known as the concept of "the three heirarchies." In the place of the three estates of medieval society (the people, the nobility, and the clergy, dominated by the last), Luther postulated three

2 From a Preface to a Disputation in 1542 , quoted in Cranz, Justice, Law, and Society, p. 140. 
"holy rules": the home, the city (meaning temporal government), and the Church. The three vocations of father, prince, and priest were equal in importance and equally "secular" or "worldly," as contrasted to Christ's holy spiritual rule in heaven. ${ }^{3}$ The home is the origin of the persons who collectively form society, and is the primary agent for training and education. The city is responsible for protection and defense of the people and for the punishment of wrongdoing. The Church, then, is the hierarchy "which must obtain people from the home and protection and defense from the city." 4 Luther is talking about the Church in the context of the office of priest, or pastor, and applied the term "church" to the office of the ministry, rather than the communio sanctorum. The three hierarchies serve together to promote civil righteousness, which, though ordained by God, does not lead to the salvation of individuals. 5

Existing in this trinity of authorities, the Church has certain "signs" which identify it and in which God reveals Himself. It also has structures through which the "signs" are made available to the people of the world, and such structures necessarily imply human authority and the rule of reason. 6 Once again, since this study deals with

IIbid., p. 174. $41: 177$.

4"On the Councils and the Church," Luther's Works,

${ }^{5}$ Cranz, Justice, Law, and Society, p. 175.

6Ibid., Pp. 150-151. 
the concept of the Church as it relates to its lay members, a full exploration of all the signs and authorities would confuse rather than clarify the issues. Therefore, three of the signs that have bearing will be considered, and the question of authority as it related to the prince and magistrate will be explored.

\section{THE SIGNS OF THE CHURCH}

Professor Rupp summarizes very briefly the seven signs which Luther said characterized the Church in "On the Councils and the Church."

1. The Preaching of the Word.

2. The Holy Sacrament of Baptism.

3. The sacrament of the Altar.

4. The Keys of Christian discipline and forgiveness.

5. A called and consecrated Christian ministry.

6. Public thanksgiving and the worship of God.

7. Suffering, the possession of the Holy Cross. 7

All of these have been touched upon, and additional consideration of the sacraments of baptism and the Lord's Supper, and the "keys of Christian discipline" will serve to illuminate something of the life of the Church in the world.

\section{The Parish Church}

Roland Bainton notes what he terms a divergence in Luther's teachings on the sacraments of baptism and the Lord's Supper. The Lord's Supper from his view is highly individualistic--each communicant standing alone before God

${ }^{7}$ Righteousness of God, p. 322. 
solely responsible for his acceptance of the promise of God. An inference that can be drawn, says Bainton, is that the Church is to be a small remnant of true believers banded together.

Baptism, on the other hand, was a "sociological sacrament," linking the Church to society and making every child a part of the Church. 8 The view is too simplistic in that it seems to view the sacraments apart from the theology which backs them, yet it does illustrate the inherent tension in Luther's teaching.

For Luther, baptism was the first step in the work of God in the individual. It was both a proclamation and the means of grace. He wrote in "Concerning the Ministry,"

For in baptizing we proffer the life-giving word of God, which renews the soul and redeems from death and sins. To baptize is incomparably greater than to consecrate bread and wine, for it is the greatest office in the church--the proclamation of the Word of God.9

In "The Holy and Blessed Sacrament of Baptism," he wrote,

The significance of baptism is a blessed dying unto sin and a resurrection in the grace of God, so that the old man, conceived and born in sin, is there drowned, and a new man, born in grace, comes forth and rises. . . Therefore sins are drowned in baptism, and in place of sin, righteousness comes forth.10

Later in the same tract, Luther explained the benefit

8Here I Stand: A Life of Martin Luther (New York: Abingdon-Cokesbury Press, 1950), p. 142 .

${ }^{9}$ Luther's Works, $40: 23$. $\quad{ }^{10}$ Luther's Works, $35: 30$. 
as twofold. First, in the promise that constitutes baptism, God "allies Himself with the individual and begins the work of grace in his soul that will be completed finally in the Last Day (the resurrection). Secondly, baptism is the pledge by the individual to die to sin more and more as he Iives. 11

This dual covenant is illustrated by an excerpt from "The Babylonian Captivity of the Church":

It will therefore be no small gain to a penitent to remember above all his baptism, and confidently calling to mind the divine promise which he has forsaken, acknowledge that promise before his Lord, rejoicing that he is still within the fortress of salvation because he has been baptized, and abhoring his wicked ingratitude in falling away from its faith and truth. 12

These statements appear to require personal responsibility on the part of the individual, seemingly cutting the foundation from beneath the practice of infant baptism. Yet for Luther the truth was in fact exactly the opposite. In his analysis of Luther's essay "Concerning Rebaptism," Jaroslav Pelikan makes this point:

- . The principle. . was not simply "that grace and faith are inseparably interrelated," but a more subtle and complex principle, namely, that faith and the word were inseparably interrelated, also in the sacraments, and moreover, that also in the sacraments "faith builds and is founded on the word of God rather than God's word on faith." I3

Baptism was then the foundational proclamation of the

11Ibid., p. 33. 12Luther's Works, 36:59.

13 Spirit Versus Structure (New York: Harper $\varepsilon$ Row, 1968), p. 78-79. 
word upon which faith could grow. And certainly it was not the rite itself that Luther considered important, as if it were some magical ceremony that accomplished a miracle of grace. Luther said,

Thus it is not baptism that justifies or benefits anyone, but it is faith in that word of promise to which baptism is added. This faith justifies, and fulfills that which baptism signifies. 14

Thus the basis for the baptism of every infant lay not primarily in the question of faith in the child, but in voluntary obedience to the command of God by the church.15 This obedience not only laid the groundwork for the individual's salvation, it also incorporated him into the Church, for in it he was consecrated to the priesthood: "The fact is that our baptism consecrates us all without exception, and makes us all priests."16 From these aspects of obedience and priesthood as they relate to baptism, these words of Luther become comprehensible:

For if, as we believe, baptism is right and useful and brings the children to salvation, and $I$ then did away with it, then I would be responsible for all the children who were lost because they were unbaptized. . . I7

Certain key implications regarding the nature of the Church in its external life have come into focus. For

14"Babylonian Captivity," Luther's Works, 36:66.

${ }^{15}$ Pelikan, Spirit Versus structure, p. 95.

16Cyril Eastwood, The Priesthood of All Believers (Minneapolis: Augsburg Publishing House, 1962), P. 20.

17"Concerning Rebaptism," Luther's Works, 40:254. 
Luther, every child born into society should be baptized for reasons of eternal salvation. Baptism also made that child part of the Church. Thus every citizen in that society necessarily had to be considered as bona fide members of and participants in the Church. Cranz writes of this:

- . Luther always assumed that there would be only one church within one earthly society; hence there is the closest connection between the invisible mode of existence of the church, its external existence with its "signs," and the secular commonwealth which includes the same Christians. And whether for the whole of Christendom or for a particular part of it such as a nation or a city, Luther is always willing to call the actual society the church. 18

Luther himself parenthetically gave expression to this position when writing against the Anabaptists: "Thus they destroy and bring to nought the parish system (ordained of God)."19 The reasonable implication is that God had ordained that all citizens of a community by virtue of baptism were equal members in the Church and shared equal rights as priests. In relation to the two kingdoms in which the Church lived, baptism emphasized the external aspect of the Church and presupposed a single universal church divided into individual congregations on the basis of geographical factors.

The Sanctified Church

Luther was not at all deceived as to the spiritual

${ }^{18}$ Justice, Law, and Society, p. 137.

19 "Infiltrating Preachers," Luther's Works, 40:385. 
sensibilities of the layman included in the Church through baptism. If anything, he underestimated the actual interest and genuine piety that did exist. Toward the end of his Iife he wrote "On the Councils and the Church," in which he listed characteristics of holy people, and then commented:

This is what is called "Christian holiness." And there must always be such people on earth, even though it may be only two or three, or only children. Unfortunately, only a few of them are old folks. 20

Another statement was quoted earlier regarding his conviction that the masses of the people would always be un-Christian.2I Yet he taught a very exclusive view of the Sacrament of the Altar.

No one should be allowed to go to communion who has not been individually examined by his pastor to see if he is prepared to go to the holy sacrament. - Whoever - . does not know why he should receive the sacrament is not to be admitted to it. In examination before the sacrament the people are to be exhorted to make confession, so that they may be instructed where cases of doubt arise in conscience, and may be comforted, when true contrition is in their hearts, as they hear the words of absolution. 22

Luther reversed the Roman interpretation of the mass, which stated that it was a sacrifice consecrated and offered by the priest to God for the forgiveness of communicants' sins. Luther held that the mass was the proclamation of God's promise to forgive sin solely on the merits of Christ's once-for-all sacrifice. As in baptism, Communion was God's

$$
20 \text { Luther's Works, 41:146-147. 21see p. } 31 \text {. }
$$
$40: 296$.

22 "Instructions to the Visitors," Luther's Works, 
gift to his people--a testament of His promise of forgiveness and eternal life. He said,

You will easily understand this as the plainest truth, if you hold it firmly that the mass is a divine promise, which can benefit no one, be applied to no one, intercede for no one, be communicated to no one, except only to the believer himself by the sole virtue of his own faith. Who can accept, on another's behalf, the promises of God, which require faith from each one individually? 23

Whereas baptism was premised primarily on obedience to the divine command and only secondarily on faith, the Lord's Supper was premised squarely on personal faith. This made the careful screening of communicants necessary, and the sacrament was reserved for the few who qualified through faith.

Another reason for the exclusiveness which Luther attached to the Sacrament lies in the implications of the doctrine of the real presence. Starting from St. Paul's. warning about receiving the sacrament unworthily, Luther held that Christ's body and blood must actually be present in the sacrament--that it coija not be merely a remembrance or symbolism, as Zwingli, Karlstadt, and the Anabaptists taught. For if the presence were dependent on the attitude of the recipient, then one could not partake of the body and blood unworthily, for if he was unworthy, the wine and bread would be for him no more than wine and bread. Since it was really possible to partake of the body and blood of Christ

23 Quoted in Eastwood, Priesthood of Believers, p. 29. 
unworthily to one's own damnation, then the pastor must be careful to administer it only to those who believed. 24

Thus for Luther, participation in the sacramental life of the Church was primarily a matter of the spirit and was focused on terms like faith, confession, absolution, and the real presence. All were in the Church by virtue of baptism, but all could not participate in the most intimately spiritual aspect of church life because of unbelief.

The Disciplined Church

Squarely between the inclusive aspect of baptism and the exclusive aspect of the Lord's Supper fell the question of church discipline or excommunication. Luther highly regarded the doctrine of the keys--the power to bind and loose sins. But he greatly emphasized the aspect of absolution--the power to loose sin--while having relatively little to say about the ban--the power to bind sin.

He wrote "Sermon on the Ban" in 1520 as he was anticipating his own excommunication from Rome. In it he made four points. First, the ban could apply only to external association with other Christians and to participation in the Sacrament: it could have nothing to do with the individual's relationship with God or his eternal salvation. Secondly, the ban was a tool of love, not vengeance or damnation. It should serve only to improve a fellow Christian, $40: 182$.

24"Against the Heavenly Prophets," Luther's Works, 
not to punish him. Only outward violations of the law (murder, thievery, adultery, etc.) should be subject to excommunication. The sins of the spirit which are hidden and secret can be judged only by God and never by man. Thirdly, the greatest danger in the use or misuse of the ban is to the persons imposing excommunication, for they must answer to God as to their motivation. Any motives other than pure love are condemned and judged by God. Fourthly, and consequently, the ban should be positively and spiritually profitable for the one banned, even if unjustly, for God responds in love to contrition. 25

These points demonstrate the inherent difficulty of church discipline in Luther's concept of the Church. Who would exercise this power? Could it be the spiritual Church against the external Church? No, because they are in reality one and the same. Could it be the true believers against worldly members? Perhaps, except that true believers are a small and persecuted minority who may or may not hold any office. Could it be "worldly" church authorities against offending members? Hardly, for their motivation probably would not be pure love, but rather a mixture with justice or duty.

It is understandable that both the ministry of absolution and the use of the ban, both so familiar in the radical

$$
25 \text { Luther's Works, } 39: 11-14 \text {. }
$$


sects, never took root in Lutheranism.26 As in the situation of administrative leadership, Luther's church lacked the means within itself to discipline itself.

\section{LUTHER'S VIEW OF PEASANTS AND PRINCES}

To this point, this chapter has dealt with the theological and theoretical nature of the external life of the Church. To complete the picture, it is necessary to discover something of what Luther thought of people as people. This is more difficult than the former because he does not anywhere give more than passing references to personal opinions. A few of these incidental statements are presented for evaluation.

The Common People

A number of references have already been made to Luther's attitude toward the common people, and these need not be restated here. To be fair to Luther and to give the tenor of his attitude, the references are arranged in chronological order, and date from 1520 to 1532 .

In his address "To the Christian Nobility" (1520) Luther made two statements that are useful at this point. In referring to the legalism of Romanism he made a statement about the warped value system that legalism had produced in the people:

26 Pelikan, Spirit Versus Structure, p. 128. 
- Consciences are so timid and fearful that it is no longer easy to preach about liberty of this kind because the common people take offence at it and think that eating butter is a greater sin than lying, swearing, or even living unchastely. 27

Secondly, in the course of the address Luther refers numerous times to the reputation of the German people as a nation of drunkards .

In 1521 in the expository sermons on "The Sermon on the Mount," Luther made suggestive comments totally unrelated to the text he was discussing. Early in the work he exhorted the common people to lightly regard material possessions and to set their interest on higher, spiritual values. The exhortation closed with, "This is said coarsely for the common man." 28 Later in the work he introduced an illustration of the Golden Rule from every day life of a manual laborer with, "To take a crude example again. . ."29

The tract "To the Councilmen of All Cities in Germany that They Establish and Maintain Christian Schools" was written in 1524. Luther observed: "I am only too well aware that we Germans must always be and remain brutes and stupid beasts as the neighboring nations call us, epithets which we richly deserve." 30 The reference to "other nations" no doubt is the taunt of Italian humanists.

In the "Instructions to the Visitors" of 1528, a point under discussion was the ringing of church bells when bad

27 Luther's Works,
$24: 184$.
29 Ibid., p. 237.


weather threatened. The people had come to regard this in a superstitious way, thinking that the ringing prevented bad weather, rather than the original purpose of the ringing, to summon the people to prayer for mercy. The tract counseled against stopping the practice, because ". . the people will become the more barbarous if they are not exhorted to pray to God for life and food." 31

In the "Exhortation to All Clergy Assembled at Augsburg" (1530) Luther refers to the ingratitude of the people, and a footnote explained that on 1 January of that year, Luther was forced to stop a sermon by the ingratitude and disobedience of the congregation. 32

As a last example, this quotation was taken from the same context referred to earlier in "Against Infiltrating and Clandestine Preachers" (1532) regarding the practice of the early church in permitting informality in preaching. 33 Luther said, "But I would not be in favor of restoring this custom and doing away with the pulpit. Rather I would oppose it, for the people are at present too untamed and forward." 34 Much caution must be taken in attributing to or reading from these incidental statements more than is fair to Luther. A superficial survey of almost any social history of the sixteenth century in Europe probably would furnish more than enough reason to say that these statements simply

$$
\begin{array}{ll}
{ }^{31} \text { Luther's Works, } & 40: 312 . \\
33 \text { See P. 16. } & 32 \text { Luther's Works, } 34: 50 . \\
34 \text { Luther's Works, } 40: 393 .
\end{array}
$$


refer to the actual objective conditions that existed, basing that judgment on current standards. Also, it is a wellrecognized fact that language used by the educated was rather more colorful and forceful than would be considered proper today.

On the other hand, adjectives such as "crude," "untamed," "barbarous," and "stupid" carry the possibility of strong emotional connotations that range from rebuke to ridicule, and instances in which Luther expressed positive approval toward the common people are singularly lacking. However, there are positive elements present in Luther's relationship to the people. For instance, his emphasis on education of children both by the church and the state, his emphasis on the social responsibilities of Christian princes and magistrates, and his interest in the spiritual welfare of the people all serve to counter an extreme interpretation of the harsher aspects of his language.

These aspects would seem to indicate that the disparaging comments should not be taken as indications of overt antipathy or hostility. Rather it would be fairer to say that they reveal an element of pessimism in Luther: He disliked the baseness and ignorance of the people, and was convinced that the situation could not be readily remedied, not in the foreseeable future. Nor did he hold the people entirely responsible for their condition. He blamed both the domination and exploitation of the curia, and the laxness 
and greed of the princes, the former for debasing the people by its legalism, the latter for neglecting their God-given responsibilities of protecting the people and putting personal desires below the welfare of the people.

The response which is most often taken as proof of Luther's antipathy to the people is his reaction to Peasants' War of 1525. But when this unfortunate episode is placed in the context of the broad outlines of both his theology and his practical teaching, the tract "Against the Robbing and Murdering Hordes of Peasants" can be made to demonstrate nothing more than Luther's attitude toward rebellion and insurrection, and the distinction is critical. It is true that Luther wrote harshly:

Furthermore, anyone who can be proved to be a seditious person is an outlaw before God and the emperor; and whoever is the first to put him to death does right and well. For if a man is in open rebellion, everyone is both his judge and his executioner; just as when a fire starts, the first man who can put it out is the best man to do the job. For rebelition is not just simple murder; it is like a great fire, which attacks and devastates a whole land. 35

Yet three years before Luther had stated his position with utmost clarity in "A Sincere Admonition by Martin Luther to All Christians to Guard Against Insurrection and Rebellion." 36 What was at stake was not the peasantry as persons, but a mob of people, irrespective of the stations

${ }^{35}$ Luther's Works, $46: 50$. ${ }_{36}$ See Quotation on p. 34 . 
of life involved, who had violently repudiated the government of God and taken up arms in disregard of $I$ aw and order. Writing about insurrection, Luther said:

It never brings about the desired improvement. For insurrection lacks discernment; it generally harms the innocent more than the guilty. Hence, no insurrection is ever right, no matter how right the cause it seeks to promote. It always results in more damage than improvement. 37

Professor Rupp makes an interesting observation of the Peasants' War:

The problem of Luther's attitude in the Peasant War is too complex to be disposed of in a paragraph . . . But at least, as they framed their cause, Luther never "let down" the Peasants, for he never took them up. Nor did he "go over to" or "fling himself into" the arms of the Princes afterwards. 38 "

Luther's position on temporal authority and order in society may be open to debate, but given his theological position, his reaction to the insurrection cannot be faulted or termed a repudiation of or change in that position. Nor can responsibility of the deaths of 100,000 peasants in the war be fairly laid at Luther's door. The princes were ruthless and vengeful, and parallels have been drawn between their conduct and Luther's harsh tract. But the record shows that the princes had been ruthless in previous uprisings, and they had no need of his advice on how to put down rebellion. If the tract had not appeared (indeed, it did

$$
\begin{aligned}
& 37 \text { Luther's Works, } 45: 62-63 . \\
& 38 \text { Righteousness of God, P. } 302, n \cdot 1 \text {. }
\end{aligned}
$$


not appear widely until after the movement had begun to collapse), the results would have been no different.

\section{The Nobility}

Luther's attitude toward the princes is, if possible, even more difficult than his attitude toward the commoners. On one hand he seemed to doubt that any but a very few were true Christians, and then on the other hand, yielded to them vast influence in the Iife of the Church. Professor Rupp summarizes Luther's opinion of their religious character:

As in 1523 he had said that "a prince is a rare bird in heaven" and that "princes are usually the greatest fools or the worst knaves on earth, therefore one must constantly expect the worst from them, and look for little good," so in 1534 he extends the judgment, "For if a prince is a rare bird in heaven, then councillors and men about court are still rarer birds in heaven." 39

Some historians feel that Luther was influenced by the better-than-average character of the Saxon electors and their advisors, 40 but the possibility of that kind of inflated opinion simply does not square with either Luther's intelligence or his own expressed pessimism about the corrupting influence of power.

There is a reason in addition to that of the unspiritual character of the princes that prevented Luther from identifying himself with them. Editor Robert Schultz notes

39 Ibid., p. 305.

40 See James Atkinson, ed. vol. 44, Luther's Works, Introduction to "To the Christian Nobility," p. 120. 
in his comments on Luther's "Admonition to Peace,"

The real problem was to defeat the devil. That victory could not be gained before the end of the world, but in the meantime the devil could be confronted and opposed wherever he was at work in opposition to the gospel and to law and order. Since he might be at work in the emperor as well as in the Turk, in the peasants as well as in the lords, and even in the church, Luther was unable to identify himself with any particular side in a conflict as though the victory of that group would establish the kingdom of God on earth. However, since the devil was fighting on so many fronts, Luther thought, the surest way to lose the battle would be to side with him by using his weapons and strategy. This consciousness that he was living in the last times made it all the more important to Luther that law and order be maintained and the gospel preached. 41

In counseling the peasant to peace, Luther emphasized that "it is not my intention to justify or defend the rulers in the intolerable injustices which you suffer from them. They are unjust, and commit heinous wrongs against you. . ."42 The absence in early Lutheranism of the means for administrative oversight and self-discipline has already been pointed out. In filling this gap, Luther acted in accordance with the implications of the doctrine of the two kingdoms. There were at least two important reasons in addition to simple practical need that he turned to the princes for aid. In his tract "Against the Heavenly Prophets in the Matter of Images and Sacraments," he condemned the way in which Karlstadt assumed the pastorate at Orlamunde, and made several revealing comments.

- I am of the opinion that the land belongs to

${ }^{41}$ Luther's Works, $46: 18$, n. 3. $\quad 42$ Ibid., p. 32 . 
the princes of Saxony and not to Dr. Karlstadt. . .43

Should not a good spirit fear God's order a little more, and since the estate, the pastorate, and the land belong to the prince, first humbly beg permission to leave and resign one position, and beg the favor of being installed in another? 44

Nor did the Orlamunders have a right to elect a pastor on another's salary, for it belonged to the prince and his jurisdiction . . .45

It appears that Luther believed that by natural right the prince had certain interests at stake in the organization and operation of the Church.

Secondly, it must be noted, as Hajo Holborn points out, that

Luther did not identify secular with ecclesiastical government. In ecclesiastical affairs the princes or magistrates were not to act as secular rulers, but as the most eminent members of the congregation. 46

And Luther himself explained the relationship:

Since those who exercise secular authority have been baptized with the same baptism, and have the same faith and the same gospel as the rest of us, we must admit that they are priests and bishops and we must regard their office as one which has a proper and useful place in the Christian community. 47

Thus Luther appealed to the princes, not as princes, but as Christians in advantageous positions to guide and protect the Church. It is his doctrine of the dual offices

43 Luther's Works, 40:116. 44Ibid., p. 112.

45 Ibid., p. 114 .

46A History of Modern Germany: The Reformation (New York: Alfred A. Knopf, 1959), p. 186.

47"To the Christian Nobility," Luther's Works, 44:129. 
of the Christian at its logical outcome. Yet the Iine of differentation was too thin for most laymen and princes to understand or maintain. The distinction is preserved as clearly as possible in this longer excerpt from the "Instructions to the Visitors," which is the clearest and most direct appeal to intervention by the prince.

Now that the gospel through the unspeakable grace and mercy of God has again come to us or in fact has appeared for the first time, and we have come to see how grievously the Christian church has been confused, scattered, and torn, we would like to have seen the true episcopal office and practice of visitation reestablished because of the pressing need. However, since none of us felt a call or definite command to do this, and St. Peter has not countenanced the creation of anything in the church unless we have the conviction that it is willed of God, no one has dared to undertake it. Preferring to follow what is certain and to be guided by love's office (which is a common obligation of Christians) we have respectfully appealed to the illustrious and noble prince and lord, John, Duke of Saxony, First Marshall and Elector of the Roman Empire, Landgrave. of Thuringia, Margrave of Meissen, our most gracious lord and prince, constituted of God as our certain temporal sovereign, that out of Christian love (since he is not obligated to do so as a temporal sovereign) and by God's will for the benefit of the Gospel and the welfare of the wretched Christians in his territory, His Electoral grace might call and ordain to this office [visitors] several competent persons. 48

Luther may have been disturbed by the way in which the princes settled themselves into this new role of ruling the church, but the die was cast, and actually had been for years prior to the writing of this excerpt. The role of the secular authority in the government of the church was an inevitable development. 
CHAPTER V

CONCLUSION

I. LUTHER AND THE CHURCH

The burden and thrust of Luther's work was directed toward the reformation, or rather the reinstatement, of the true spiritual character of the Church as he understood it from Scripture and the patristic writers. He envisioned the Church as a community of believers living under the sole authority of Scripture, and exercising on behalf of one another all the offices of the priesthood. This universal priesthood of the believer was bestowed through Christian baptism and became operational in justification by faith. through the hearing of the Spirit-indited living Word. Such persons were totally free of any external restraints or restrictions concerning either moral or ceremonial matters, for they were taught of God and voluntarily and gladly followed His, and only His, leadership.

At the same time, Luther was fully persuaded that true Christians were exceedingly few and far between. This holy communion of saints, the spiritual Church, was and would always be a small, unassuming, and persecuted minority in a world that viewed its characteristic love, faith, and meekness as weakness. Even more, this spiritual Church was 
hidden in the external, world Church and only God knew for certain who were the true Christians. And the external Church had a disposition to make things difficult for its spiritually inclined members. Thus each Christian lived in the two kingdoms of heaven and of the world, between which there was an unavoidable moral tension, and he was a part of the Church, which also existed in the two kingdoms and demonstrated the same tension.

\section{COUNTERCURRENTS IN LUTHER'S THOUGHT}

The theological and theoretical idealism that was inherent in Luther's thought and writing concerning the spiritual Church and the practice of the priesthood of all believers came into conflict with several factors inherent in Luther's own personality.

First, Luther was undeniably a political and social conservative. The fact is not a fault or shortcoming, and it should not be attributed in a simplistic manner to his early life of poverty, his possibly authoritarian father, or his education. Rather it was a complex interrelation of these and other factors coupled with the natural dispositional differences that make humans individuals. In another person the influences that bore on Luther might have produced a social and political radical. But in Luther the conservatism that characterized his view of political and social structures caused him to resist and fear changes in those structures. 
Secondly, Luther was a social pessimist. He viewed the masses, not with hostility or aversion, but with a mild disgust. He saw ignorance, superstition, sensuality, and materialism in them, and was convinced that improvement was difficult and gradual, if possible at all. Contributing to this view was his theological position that held that men were totally and willfully depraved and lacking in any good impulse unless acted upon by the grace of God.

Thirdly, Luther was reactionary in a limited sense. He identified any pressure for external change with the cause of the radical reformers, and especially the Anabaptists. He deliberately delayed certain reforms that he felt to be advisable for no other reason than that the radicals were demanding those very reforms. He went no farther in external change than absolutely necessary to incorporate. evangelical doctrine in the structures of the external church. His adversion to the disseminators of what he saw as subjective theology and political sedition also extended to the external changes demanded by those persons.

Fourthly, Luther was convinced, quite apart from his position regarding the radical reformers, that one could never alter the internal spirit by changing or rearranging external structures. Rather, the external structures were nothing more than the expressions of the spirit, and if the spirit was reformed and revitalized, necessary changes would naturally come in the external structures, and that without 
disorder and chaos.

\section{LUTHER'S CHURCH IN RETROSPECT}

The theological idealism implicit in the doctrine of the priesthood of the believer was inevitably undercut by the four factors presented in the preceding paragraphs. This process of modification is revealed in at least four ways.

First, Luther's theological position on the existence and nature of the two kingdoms, and the indiscriminate application of that doctrine to the Church forced modification in the practice of the theological ideal. The doctrine required the inclusion into the Church of large numbers of baptized but unbelieving Christians who had not the spirit or desire to function as part of the communio sanctorum, and yet in all points were on an equal footing as equal members with the true believers in the extemal Church.

Secondly, Luther never instituted nor saw the need of any formal or recognized structures in the Church through which the Scriptural characteristics of the communio sanctorum could be encouraged or channeled. If true believers were to minister to each other in the various offices of priesthood that were theirs by virtue of baptism and faith, they had to do so privately, and totally outside the external structures of the Church. Such private practice was indeed possible, and Luther seemed to be satisfied that if 
it were possible, then the Holy spirit would take care of the rest.

Thirdly, the inclusion of non-believers in the Church by virtue of baptism made it increasingly apparent to Luther that an educated, ordained clergy was indispensable to the maintenance of order in the church. The non-believer would not and could not respond to the leadership of God, and thus must be controlled by external authority. Thus the public practice of the duties of priesthood was delegated to the pastor to prevent public disorder. Since the Church was mostly made up of non-believing Christians, it appeared that only the minister exercised these rights, since the true believers whom he represented were in the minority and nonassertive. The groundwork was laid for a sense of distance, now within the Church between pastor and people, rather than between Church and laity as it had been before the Reformation.

Fourthly, the absence of administrative and disciplinary means within the Church necessitated the appeal to secular authorities to intervene as Christian laymen. This quasiofficial state authority in the Church came to rival or replace the centrality of the authority of the Bible in matters of practice and conduct, for the people viewed the parish visitors appointed by the prince as his representatives, backed by his political authority. The distinctions that Luther drew to prevent this were too fine and too theoretical to be maintained. 
IV. CONCLUSION

It is evident, then, that there were modifications in Luther's position on the priesthood of the believers during the course of his career, but that these were of a practical rather than a theological nature. It is equally evident that these modifications were not the result of personal antipathies or attractions that Luther held toward particular classes, but arose from theological and personality factors within himself. Very simply, the thesis question for this study must be answered in the negative. 


\section{SELECTED BIBLIOGRAPHY}

\section{GENERAL AND SECONDARY SOURCES}

Althus, Paul. The Theology of Martin Luther. Translated by Robert C. Schultz. Philadelphia: Fortress Press, 1966 .

Bainton, Roland H. Here I Stand: A Life of Martin Luther. New York: Abingdon-Cokesbury Press, 1950.

Bornkamm, Heinrich. Luther's Doctrine of Two Kingdoms. Translated by Karl H. Hertz. Social Ethics Series, no. 14. Gen. ed. Franklin Sherman. Philadelphia:

Fortress Press Facet Books, 1966.

Bruce, F. F., gen. ed. The Advance of Christianity Through the Centuries. 8 vols. Grand Rapids, Michigan:

Wm. B. Eerdmans Publishing Co., 1968. Vol. 4: The Great Light: Luther and Reformation, by James Atkinson.

Cranz, F. Edward. An Essay on the Development of Luther's Thought on Justice, Law, and Society. Harvard TheoIogical Studies, no. 19. Cambridge: Harvard University Press, 1964.

Dickens, A. G. Reformation and Society in Sixteenth-Century Europe. London: Harcourt, Brace, E Norld, 1966.

Eastwood, Cyril. The Priesthood of All Believers. Minneapolis: Augsburg Publishing House, 1962.

Elton, G. R. Reformation Europe, 1517-1559. New York: Harper \& Row, 1963 .

Engels, Frederich. The Peasant War in Germany. New York: International Publishers, 1926.

Erickson, Erik. Young Man Luther. New York: W. W. Norton \& Co., 1958.

Headley, John M. Luther's View of Church History. New Haven, Conn.: Yale University Press, 1963. 
Holborn, Hajo. A History of Modern Germany: The Reformation. New York: Alfred A. Knopf, 1959.

Hyma, Albert. New Light on Martin Luther. Grand Rapids, Mich.: Wm. B. Eerdmans Publishing Co., 1958.

Kadai, Heino 0. , ed. Accents in Luther's Theology. St. Louis: Concordia Publishing Co., 1967.

Lautourette, Kenneth Scott. A History of Christianity. New York: Harper \& Row, 1953.

Lucas, Henry S. The Renaissance and the Reformation. New York: Harper \& Row, 1934 .

Noll, Mark A. "Believer-Priests in the Church: Luther's View." Christianity Today, October 26, 1973, pp. 4-8.

Pelikan, Jaroslav, ed. Interpreters of Luther. Philadelphia: Fortress Press, 1968.

- Spirit Versus Structure. New York: Harper \& Row, 1968 .

Rupp, Gordon. The Righteousness of God. London: Hodder $\&$ Stoughton, 1953 .

\section{SELECTIONS FROM LUTHER"S WORKS}

Pelikan, Jaroslav, and Helmut T. Lehmann, eds. Luther's Works, American Edition. Philadelphia: Fortress Press and Concordia Publishing Co., 1955.1

"Admonition to Peace, A Reply to the Twelve Articles of the Peasants of Swabia." 1525. 46:3-44.

"Against Hanswurst." 1541. 41:179-256.

"Against the Heavenly Prophets in the Matter of Images and Sacraments." 1525. 40:79-223.

"Against the Robbing and Murdering Hordes of Peasants." 1525. $46: 45-56$.

"Against the Roman Papacy, an Institution of the Devil." 1545. 41:257-376.

IThe following works by Luther are all found in this edition of his works, and are alphabetically listed by title, with the original date of publication and location. 
"Against the Spiritual Estate of the Pope and the Bishops, Falsely So Called." 1522. 39:239-355.

"Answer to the Hyperchristian, Hyperspiritual, Hyperlearned, Book by Goat Enser in Leipzig--Including Some Thoughts Regarding His Companion, the Fool Murner." 1521. 39: 137-224.

"The Babylonian Captivity of the Church." 1520. 36:3-126.

"The Blessed Sacrament of the Holy and True Body of Christ, and the Brotherhoods." 1519. 35:45-74.

"Brief Confession Concerning the Holy Sacrament." 1544. $38: 279-320$.

"Concerning Rebaptism." 1528. 40:227-267.

"Concerning the Answer of the Goat in Leipzig." 1521. $39: 117-136$.

"Concerning the Ministry." 1523. 40:5-44.

"A Discussion on How Confession Should Be Made." 1520. $39: 23-48$.

"Dr. Luther's Retraction of the Error Forced upon Him by the Most Highly Learned Priest of God, Sir Jerome Emser, vicar in Meissen." 1521. 39:225-238.

"Dr. Martin Luther's Warning to His Dear German People." 1531. $47: 3-56$.

"Exhortation to All Clergy Assembled at Augsburg." 1530 . $34: 3-62$.

"The Freedom of a Christian." 1520. 31:327-378.

"The Holy and Blessed Sacrament of Baptism." 1519. 35: $23-44$.

"Infiltrating and Clandestine Preachers." 1532. 40:381-394.

"Instructions for the Visitors of Parish Pastors in Electoral Saxony." 1528. 40:263-320.

"An Instruction to Penitents Concerning the Forbidden Books of Dr. M. Luther." 1521. 44:220-231.

"The Judgment of Martin Luther on Monastic Vows." 1521. 44:243-400.

"The Keys." 1530. 40:371-378. 
"Letter to the Christians at Strassburg in Opposition to the Fanatic Spirit." 1524. 40:21-72.

"Letter to the Princes of Saxony Concerning the Rebellious Spirit." 1524. 40:45-60.

"On the Councils and the Church." 1539. 41:3-178.

"On the Papacy in Rome, Against the Most Celebrated Romanist in Leipzig." 1521. 39:49-104.

"On war Against the Turk." 1529. 46:155-206.

"An Open Letter on the Harsh Book Against the Peasants." 1525. $46: 57-86$.

"Ordinance of a Common Chest, Preface." 1523. 45:159-175.

"A Sermon on the Ban." 1520. 39:3-72.

"The Sermon on the Mount (Sermons)." 1521. 21:1-294.

"A Sermon on the Three Kinds of Good Life for the Instruction of Consciences." 1521. 44:232-242.

"A Sincere Admonition by Martin Luther to A11 Christians to Guard Against Insurrection and Rebellion." 1522. 45:51-74.

"Temporal Authority: To What Extent it Should be Obeyed." 1523. $45: 75-130$.

"That a Christian Assembly or Congregation Has the Right and Power to Judge All Teaching and to Call, Appoint, and Dismiss Teachers, Established and Proven by Scripture." 1523. 39:303-314.

"To the Christian Nobility of the German Nation Concerning the Reform of the Christian Estate." 1520. 44:115219 .

"To the Goat in Leipzig." 1521. 39:105-116. 